\title{
Aquatic macrophytes in natural and managed wetlands of Rio Grande do Sul State, Southern Brazil
}

\author{
Macrófitas aquáticas em áreas úmidas naturais e \\ manejadas do Rio Grande do Sul, sul do Brasil
}

Ana Silvia Rolon, Henrique Flores Homem and Leonardo Maltchik

Ecologia e Conservação de Ecossistemas Aquáticos, Universidade do Vale do Rio dos Sinos - UNISINOS, CEP 93022-000, São Leopoldo, RS, Brazil

e-mail: asrolon@gmail.com, hfhomem@gmail.com, maltchik@unisinos.br

\begin{abstract}
Aim: This study gathers the main results obtained from studies regarding dynamic of aquatic macrophyte community in natural and managed wetlands of Southern Brazil. We analyzed the aquatic macrophytes diversity in wetlands of Southern Brazil, the environmental factors that determine the structure of the aquatic macrophyte community in fragmented wetlands, the effects of floods on the dynamics of macrophytes, and the contributions to the rice field for the conservation of aquatic macrophytes; Methods: The information was obtained from several researches carried in several spatial scales and different wetlands types over the last 10 years in Southern Brazil; Results: The studies have reported the occurrence of approximately 250 species of aquatic macrophytes. Wetland area, habitat diversity, altitude and hydroperiod were determinant for macrophyte richness and composition in wetlands of Southern Brazil. Furthermore, flood events, long or short-term ones, are strongly associated to the structure of the aquatic macrophyte community. The rice field systems of Southern Brazil (crops and irrigation channel) shelter a representative number of species of macrophyte found at natural wetlands in this region. The agricultural practices adopted over rice cultivation cycle in the rice fields have influenced the macrophyte richness and biomass. The different hydrological management practices adopted after the harvesting period (presence or lack of water surface) did not influence the macrophyte richness and biomass, however it influenced the species composition; Conclusions: The increasing process of wetland degradation (e.g. fragmentation, flood control and rice field expansion) presents a threat to the conservation aquatic macrophyte species.
\end{abstract}

Keywords: aquatic plant, diversity, conservation, Neotropical region.

Resumo: Objetivo: Este estudo reúne os principais resultados obtidos em trabalhos sobre a dinâmica da comunidade de macrófitas aquáticas em áreas úmidas naturais e manejadas do sul do Brasil. Nós analisamos a diversidade de macrófitas aquáticas do sul do Brasil, os fatores ambientais que determinam a estrutura da comunidade de macrófitas aquáticas nas áreas úmidas, o efeito das inundações na dinâmica da comunidade e a contribuição dos arrozais para a conservação das macrófitas aquáticas; Métodos: As informaçôes foram obtidas de vários trabalhos realizados em diversas escalas espaciais e diferentes tipos de áreas úmidas ao longo dos últimos 10 anos no sul do Brasil; Resultados: Os estudos têm reportado a ocorrência de aproximadamente 250 espécies de macrófitas aquáticas. $\mathrm{O}$ tamanho da área úmida, diversidade de habitats, altitude e hidroperíodo foram determinantes para a riqueza e a composição de espécies em áreas úmidas do sul do Brasil. Além disso, os eventos de inundação, de longa ou curta duração, estão fortemente relacionados à estrutura da comunidade de macrófitas. Os sistemas orizícolas sul do Brasil (lavouras e canais de irrigação) abrigam um número representativo de espécies de macrófitas aquáticas encontradas em áreas úmidas naturais dessa região. As práticas agrícolas adotadas ao longo do ciclo de cultivo nos arrozais influenciaram a biomassa e a riqueza de macrófitas. As práticas de manejo adotadas no período póscolheita (presença ou ausência de água superficial) não influenciaram a riqueza e a biomassa de macrófitas, mas influenciaram a composição de espécies; Conclusóes: $\mathrm{O}$ aumento do processo de degradação das áreas úmidas (e.g. fragmentação, controle de inundaçóes e expansão de arrozais) constitui uma ameaça a conservação das espécies de plantas aquáticas.

Palavras-chave: planta aquática, diversidade, conservação, região Neotropical. 


\section{Introduction}

Wetlands are important sites for biological conservation because they support a rich biodiversity and present high productivity (Mitsch and Gosselink, 2000). However, biodiversity in wetlands has been reduced worldwide (Shine and Klemm, 1999) - a loss of more than $50 \%$ of these ecosystems in the last century due to human activities (Shine and Klemm, 1999). Subtropical and tropical wetlands have come under increasing pressure since the 1950s, and the wetland loss in South America over the 90's decade was estimated at $6 \%$ of total wetlands of continent (OECD, 1996). The impact of wetland loss on biodiversity was verified by the decline of populations of several wetland-dependent species (Millennium Ecosystem Assessment, 2005).

The fragmentation of wetlands is one of the main problems related to the conservation of the biodiversity. The change in the landscape has caused a reduction in the area and connectivity of natural habitats. Understanding the biodiversity patterns in fragmented wetlands of the Southern Brazil is extremely important to guide policies for biodiversity conservation. The principle that a large area supports more species (Arrhenius, 1921; Rosenzweig, 1995) has been put into practice in conservational planning. By assuming wetlands to be ecological islands surrounded by terrestrial habitats, the relationships among species richness and wetland size were extensively used for wetland management (Hall et al., 2004).

Agriculture is one of the main human activities responsible for the decline of natural wetlands throughout the world, being the conservation of the species jeopardized by the impact of irrigated agriculture expansion (Millennium Ecosystem Assessment, 2005). Rice is the most important cereal crop in the developing world (Juliano, 1993). In 2003, approximately 151 million ha of land were cultivated with rice worldwide (FAOSTAT, 2008). Biodiversity conservation in agricultural landscape is an ecological challenge (Marshall et al., 2003). Several studies have demonstrated the contribution of managed ecosystems, like as, rice fields and irrigation channels, providing habitats for establishment of aquatic organisms (Elphick, 2000; Goulder, 2008; Herzon and Helenius, 2008).

Wetland studies are important in Brazil, mainly because we are referring to a country with the highest rates of biodiversity and freshwater ecosystems (Agostinho et al., 2005; Lewinsohn and Prado, 2005). The hydrological characteristic of Southern Brazil is the high diversity and density of wetlands; approximately $11 \%$ of total area of Rio Grande do Sul State (Maltchik et al., 2003). In Southern Brazil, approximately $72 \%$ of wetlands are smaller than $1 \mathrm{~km}^{2}$ (Maltchik, 2003). This strong fragmentation is due to agricultural expansion, mainly irrigated rice fields (Gomes and Magalhães, 2004). Conservative estimates indicate that approximately $90 \%$ of wetlands have disappeared in Southern Brazil (Maltchik, 2003). The increasing process of degradation of these ecosystems presents a threat to the aquatic biodiversity conservation in Southern Brazil, including the aquatic macrophytes.

This study gathers the main results obtained from several studies carried out over the last 10 years to identify the spatial and temporal dynamics of aquatic macrophytes in wetlands of Rio Grande do Sul. The main goals were to: (1) carry out a survey of the aquatic macrophytes diversity in wetlands of Rio Grande do Sul; (2) analyse the effects of environmental factors that determine the structure of the aquatic macrophytes in fragmented wetlands, (3) investigate the effects of floods on the dynamics of macrophytes, and (4) analyse the contributions to the rice field for the conservation of aquatic macrophytes. This study gathers information obtained from several researches carried in several spatial scales and different wetlands types (e.g. marshes, shallow lakes, oxbow lakes and rice fields). Such information may be used as base for planning the conservational guidelines and the sustainable use of the wetlands of Southern Brazil.

\section{Methods}

The influence of environmental variables on the macrophyte richness and composition of the species was analysed in three spatial scales: the Rio Grande do Sul State (Rolon and Maltchik, 2006), the middle part of the Coastal Plain (Rolon et al., 2008), and the Rio do Sinos basin (Maltchik et al., 2002). Such studies were carried along eight years (2000-2007). The effect of floods on the structure of the macrophyte community was investigated in wetlands of the Rio dos Sinos basin between 2000 and 2005 (Maltchik et al., 2004, 2005, 2007; Schott et al., 2005). The diversity and the dynamics of aquatic macrophytes in rice fields in Southern Brazil were assessed in six rice fields (Rolon and Maltchik, 2010) and in four irrigation channels (unpublished data) of the Coastal Plain of Rio Grande do Sul between 2006 and 2007. The survey of aquatic macrophyte biodiversity was carried between 2000 and 2009. 


\section{Results and Discussion}

\subsection{Diversity of aquatic macrophytes in wetlands of Southern Brazil}

Our studies carried recently in wetlands in Southern Brazil, which focused on different spatial scales, have reported the occurrence of approximately 250 species of aquatic macrophytes (Maltchik et al., 2002; Bertoluci et al., 2004; Rolon et al., 2004; Rolon et al., 2008) (Table 1). The species richness of aquatic macrophytes of Rio Grande do Sul is estimated around 500 species (Irgang and Gastal, 1996); however, such estimation was based on a larger number of habitats, including the estuarine wetlands and the great lakes of the Coastal Plain.

The assemblage of aquatic macrophyte from wetlands of Southern Brazil is represented by a variety of biological types (submerged, floating, emergent and amphibious) and taxonomic groups, since macro-algae until angiosperms. The emergent species are dominant in wetlands of Southern Brazil and in this group, Cyperaceae, Poaceae and Asteraceae are the outstanding families. The highest level of dominance in number of emergent species in relation to the number of hydrophyte species (floating and submerged) in the wetlands is related to the shallowness of the wetlands as well as to the intermittent character of some systems.

Some species of aquatic macrophyte such as Luziola peruviana, Ludwigia peploides, Polygonum punctatum and Nymphoides indica are among the most frequent species of the wetlands of Southern Brazil (Rolon et al., 2004). Nevertheless, the majority of the species has presented low occurrence rate, indicating high spatial variability in the macrophyte community. Such spatial variability ( $\beta$-diversity) is a very important characteristic for the wetlands conservation.

The distribution of aquatic macrophytes occurs heterogeneously in Rio Grande do Sul (Figure 1). The areas with high diversity of aquatic macrophytes are at the middle part of the Coastal Plain of Rio Grande do Sul, while the areas with low diversity are distributed along the Upland at the Northern part of the state.

The differences in the richness of aquatic macrophytes at the wetlands may result from the environmental heterogeneity in the landscape scale (e.g. altitude variations, size of the ecosystems, hydroperiod, connectivity and environmental matrix) or in micro-scales (e.g. habitat diversity and physic-chemical conditions of the water and sediment).

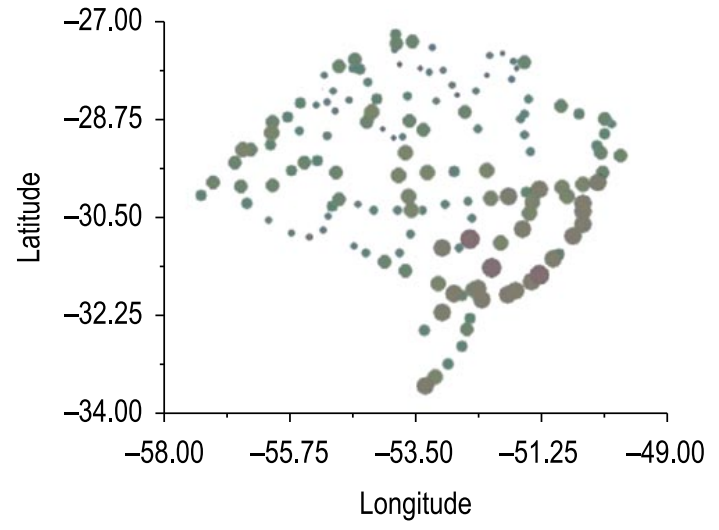

Figure 1. Distribution of aquatic macrophyte richness in wetlands of Rio Grande do Sul State. The large points represent wetlands with high diversity of aquatic macrophytes and small points represent poor-richness wetlands.

\subsection{Environmental gradients and macrophyte diversity in fragmented wetlands of Southern Brazil}

The area is one of the main environmental parameters related to the richness of aquatic macrophyte (Oertli et al., 2002; Jones and Maberly, 2003; Dahlgren and Ehrlén, 2005). In Southern Brazil, the macrophyte richness, in general, is conditioned by wetland area in different spatial scales (Maltchik et al., 2002; Rolon and Maltchik, 2006; Rolon et al., 2008). The high species richness in larger areas may be the direct result of an increase in potential areas for colonization (the area effect per se, Kohn and Walsh, 1994; Ricklefs and Lovette, 1999). However, there are other hypotheses for the joint increase of species richness and area. The habitat diversity hypothesis suggests that the number of species increases as area increases because the number of habitat rises (Kohn and Walsh, 1994; Ricklefs and Lovette, 1999). However, it is difficult to assess the independent effects of area and habitat diversity on richness because usually they are highly correlated (Ricklefs and Lovette, 1999). In wetlands of Coastal Plain of Southern Brazil, it was noticed that both area per se and habitat diversity determined macrophyte species richness (Rolon et al., 2008).

The altitude was a limiting factor for the macrophyte richness in Southern Brazil wetlands (Rolon and Maltchik, 2006). Nevertheless, the effect of altitude on macrophyte richness was correlated to the area effects, making it difficult to assess the proportional contribution of each of these variables to species richness (Rolon and Maltchik, 2006). The connectivity of the wetlands is another factor related to the variation of altitude in Southern Brazil and it is possibly important for the structure 
Table 1. Aquatic macrophyte species in wetlands of Southern Brazil.

\begin{tabular}{|c|c|c|}
\hline & Family & Species \\
\hline \multirow[t]{4}{*}{ Charophyta } & CHARACEAE & Nitella sp.1 \\
\hline & & Nitella sp.2 \\
\hline & & Nitella sp.3 \\
\hline & & Nitella sp.4 \\
\hline \multirow[t]{3}{*}{ Briophyta } & SPHAGNACEAE & Sphagnum sp. \\
\hline & RICCIACEAE & Riccia stenophylla Spruce \\
\hline & & Ricciocarpus natans (L.) Corda \\
\hline \multirow[t]{9}{*}{ Pteridophyta } & EQUISETACEAE & Equisetum giganteum $\mathrm{L}$. \\
\hline & LYCOPODIACEAE & Lycopodium alopecuroides $\mathrm{L}$. \\
\hline & MARSILEACEAE & Marsilea ancylopoda A. Braun \\
\hline & & Regnellidium diphyllum Lindm. \\
\hline & PTERIDACEAE & Acrostichum sp. \\
\hline & SALVINIACEAE & Azolla filiculoides Lam. \\
\hline & & Salvinia herzogii de la Sota \\
\hline & & Salvinia minima Bak. \\
\hline & THELYPTERIDACEAE & Thelypteris sp. \\
\hline \multirow[t]{34}{*}{ Magnoliophyta } & ACANTHACEAE & Hygrophila brasiliensis (Spr) Lindau \\
\hline & & Hygrophila guaianensis Nees \\
\hline & & Hygrophila helodes Nees \\
\hline & ALISMATACEAE & Echinodorus grandiflorus (Cham \& Schl.) Michx. \\
\hline & & Echinodorus longiscapus Arech. \\
\hline & & Echinodorus tenellus (Mart.) Buch. \\
\hline & & Sagittaria montevidensis Cham \& Schl. \\
\hline & AMARANTHACEAE & Alternanthera brasiliana (L.) Kuntze \\
\hline & & Alternanthera philoxeroides (Mart.) Gris. \\
\hline & APIACEAE & Centella asiatica (L.) Urb. \\
\hline & & Eryngium eburneum Decne. \\
\hline & & Eryngium horridum Malme \\
\hline & & Eryngium pandanifolium Cham \& Schl. \\
\hline & & Eryngium sp. \\
\hline & & Lilaeopsis brasiliensis (Glaziou) Affolter \\
\hline & & Lilaeopsis carolinensis Coutter \& Rose \\
\hline & ARACEAE & Colocasia esculenta (L.) Schott. \\
\hline & & Lemna minuta Kunth \\
\hline & & Lemna valdiviana Phil. \\
\hline & & Pistia stratiotes $\mathrm{L}$. \\
\hline & & Spirodela intermedia W. Koch \\
\hline & & Wolffia brasiliensis Wedell \\
\hline & & Wolffiella lingulata (Hegelm.) Hegelm. \\
\hline & & Wolffiella oblonga (Phil.) Hegelm. \\
\hline & & Zantedeschia aethiopica (L.) Spr. \\
\hline & ARALIACEAE & Hydrocotyle bonariensis Lam. \\
\hline & & Hydrocotyle ranunculoides L. f. \\
\hline & & Hydrocotyle verticillata Thumb \\
\hline & ASTERACEAE & Aster squamatus (Spreng.) Hier. \\
\hline & & Baccharis microcephala (Less.) DC. \\
\hline & & Baccharis trimera (Less.) DC. \\
\hline & & Bidens laevis (L.) B.S.P. \\
\hline & & Bidens pilosa $\mathrm{L}$. \\
\hline & & Conyza pampeana (Parodi) Cabrera \\
\hline
\end{tabular}


Table 1. Continued...

\begin{tabular}{|c|c|c|}
\hline & Family & Species \\
\hline Magnoliophyta & $\begin{array}{l} \\
\text { CABOMBACEAE } \\
\text { CAMPANULACEAE } \\
\text { CERATOPHYLLACEAE } \\
\text { CLEOMACEAE } \\
\text { COMMELINACEAE } \\
\text { CONVOLVULACEAE } \\
\text { CYPERACEAE }\end{array}$ & $\begin{array}{l}\text { Cotula coronopifolia L. } \\
\text { Enydra anagallis Gardner } \\
\text { Eupatorium sp } \\
\text { Gymnocoronis spilanthoides (Don.) DC. } \\
\text { Hypochoeris sp } \\
\text { Jaegeria hirta (Lag.) Less. } \\
\text { Mikania micrantha H. B. K. } \\
\text { Mikania sp. } \\
\text { Pluchea sagittalis (Lam.) Cabr. } \\
\text { Senecio bonariensis H. \& A. } \\
\text { Senecio brasiliensis Less. } \\
\text { Senecio jurguensii Less. } \\
\text { Senecio tweediei Hook \& Arn. } \\
\text { Vernonia nudiflora Less. } \\
\text { Begonia cucullata Willd. } \\
\text { Cabomba caroliniana A. Gray } \\
\text { Pratia hederacea (Cham.) G. Don } \\
\text { Ceratophyllum demersum L. } \\
\text { Cleome hassleriana Chodat } \\
\text { Commelina diffusa Burm.f } \\
\text { Floscopa glabrata (Kunth) Hassk. } \\
\text { Ipomoea cairica (L.) Sweet. } \\
\text { Androtrichum trigynum (Spreng.) H.Pfeiff. } \\
\text { Bulbostylis capillaris (L.) C.B. Clarke } \\
\text { Carex sp. } \\
\text { Cyperus barrosianus Herter } \\
\text { Cyperus berroi (C. B. Cl.) Barros } \\
\text { Cyperus difformis L. } \\
\text { Cyperus esculentus L. } \\
\text { Cyperus ferax Rich. } \\
\text { Cyperus giganteus Vahl. } \\
\text { Cyperus haspan L. } \\
\text { Cyperus hermaphroditus (Jacq.) Stand. } \\
\text { Cyperus imbricatus Retz. } \\
\text { Cyperus intricatus Schr. \& Schult. } \\
\text { Cyperus laetus Kunth } \\
\text { Cyperus lanceolatus Poir. } \\
\text { Cyperus luzulae (L.) Retz } \\
\text { Cyperus megapotamicus Kunth } \\
\text { Cyperus polystachyos Rottb. } \\
\text { Cyperus prolixus H.B.K. } \\
\text { Cyperus reflexus Vahl } \\
\text { Cyperus sesquiflorus (Torrey) Mattf. \& Kük } \\
\text { Cyperus surinamensis Rottb. } \\
\text { Eleocharis acutangula (Roxb) Schult. } \\
\text { Eleocharis bonariensis Nees } \\
\text { Eleocharis elegans (Kunth) Roem. \& Schult. } \\
\text { Eleocharis interstincta (Vahl) Roem. \& Schult. } \\
\text { Eleocharis maculosa (Vahl) Roem \& Schult } \\
\text { Eleocharis minima Kunth } \\
\text { Eleocharis radicans (Poir.) Kunth } \\
\text { Eleocharis sellowiana Kunth } \\
\text { Eleocharis viridans Kük. ex Osten } \\
\text { a }\end{array}$ \\
\hline
\end{tabular}


Table 1. Continued...

\begin{tabular}{|c|c|c|}
\hline & Family & Species \\
\hline \multirow{14}{*}{\multicolumn{2}{|c|}{ Magnoliophyta }} & Fimbristylis autumnalis (L.) Roem. \& Schult. \\
\hline & & Fimbristylis dichotoma (L.) Vahl. \\
\hline & & Fimbristylis sp. \\
\hline & & Fimbristylis squarrosa Vahl \\
\hline & & Kyllinga odorata Vahl \\
\hline & & Kyllinga vaginata Lam. \\
\hline & & Oxycaryum cubense (Poepp. \& Kunth) Palla \\
\hline & & Rhynchospora barrosiana Guagl. \\
\hline & & Rhynchospora brittonii Gale \\
\hline & & Rhynchospora corymbosa (L.) Britton \\
\hline & & Rhynchospora holoschoenoides (Rich.) Herter \\
\hline & & Schoenoplectus californicus (C.A. Mey.) Soják \\
\hline & & Scirpus sp. \\
\hline & & Scirpus submersus C. Wright \\
\hline & DROSERACEAE & Drosera brevifolia Pursh \\
\hline & ERIOCAULACEAE & Eriocaulon modestum Kunth \\
\hline & \multirow[t]{2}{*}{ EUPHORBIACEAE } & Sebastiania commersoniana (Baill.) L.B. Smith \& R.J. Downs \\
\hline & & Sebastiania schottiana (M. Arg.) M.Arg. \\
\hline & \multirow[t]{9}{*}{ FABACEAE } & Bauhinia forficata Link \\
\hline & & Desmodium adscendens (Sw.) DC. \\
\hline & & Erythrina crista-galli L. \\
\hline & & Inga uruguensis Hook. \& Arn. \\
\hline & & Mimosa bimucronata (DC) O Kze \\
\hline & & Sesbania punicea (Cav.) Benth \\
\hline & & Sesbania virgata (Cav.) Pers. \\
\hline & & Vigna longifolia (Benth.) Verdc. \\
\hline & & Vigna luteola (Jacq.) Benth. \\
\hline & \multirow[t]{2}{*}{ HALORAGACEAE } & Laurembergia tetrandra (Schott ex Spreng.) Kanitz \\
\hline & & Myriophyllum aquaticum (Vell.) Verdcourt \\
\hline & HALORAGACEAE & Proserpinaca palustris L. \\
\hline & \multirow[t]{3}{*}{ HYDROCHARITACEAE } & Egeria densa Planch. \\
\hline & & Limnobium laevigatum (Humb. \& Bonpl. ex Willd.) Heine \\
\hline & & Najas microdon A. Br. \\
\hline & \multirow[t]{9}{*}{ JUNCACEAE } & Juncus bufonius L. \\
\hline & & Juncus capillaceus Lam. \\
\hline & & Juncus dombeyanus Gay \\
\hline & & Juncus effusus L. \\
\hline & & Juncus marginatus Rostk. \\
\hline & & Juncus microcephalus H.B.K. \\
\hline & & Juncus pallescens Lam. \\
\hline & & Juncus scirpoides Lam. \\
\hline & & Juncus sellowianus Kunth \\
\hline & \multirow[t]{2}{*}{ LAMIACEAE } & Hyptis balansae Briq. \\
\hline & & Hyptis fasciculada Benth. \\
\hline & \multirow[t]{6}{*}{ LENTIBULARIACEAE } & Utricularia foliosa L. \\
\hline & & Utricularia gibba L. \\
\hline & & Utricularia inflata Walter \\
\hline & & Utricularia praelonga A.St.-Hil. \& Girard \\
\hline & & Utricularia subulata L. \\
\hline & & Utricularia tricolor A. St.-Hil. \\
\hline & LIMNOCHARITACEAE & Hydrocleys nymphoides (Willd.) Buch. \\
\hline & LINDERNIACEAE & Micranthemum umbrosum (Walter) Blake \\
\hline & LYTHRACEAE & Cuphea carthagenensis (Jacq.) Macbride \\
\hline & MAYACACEAE & Mayaca fluviatilis Aubl. \\
\hline
\end{tabular}


Table 1. Continued...

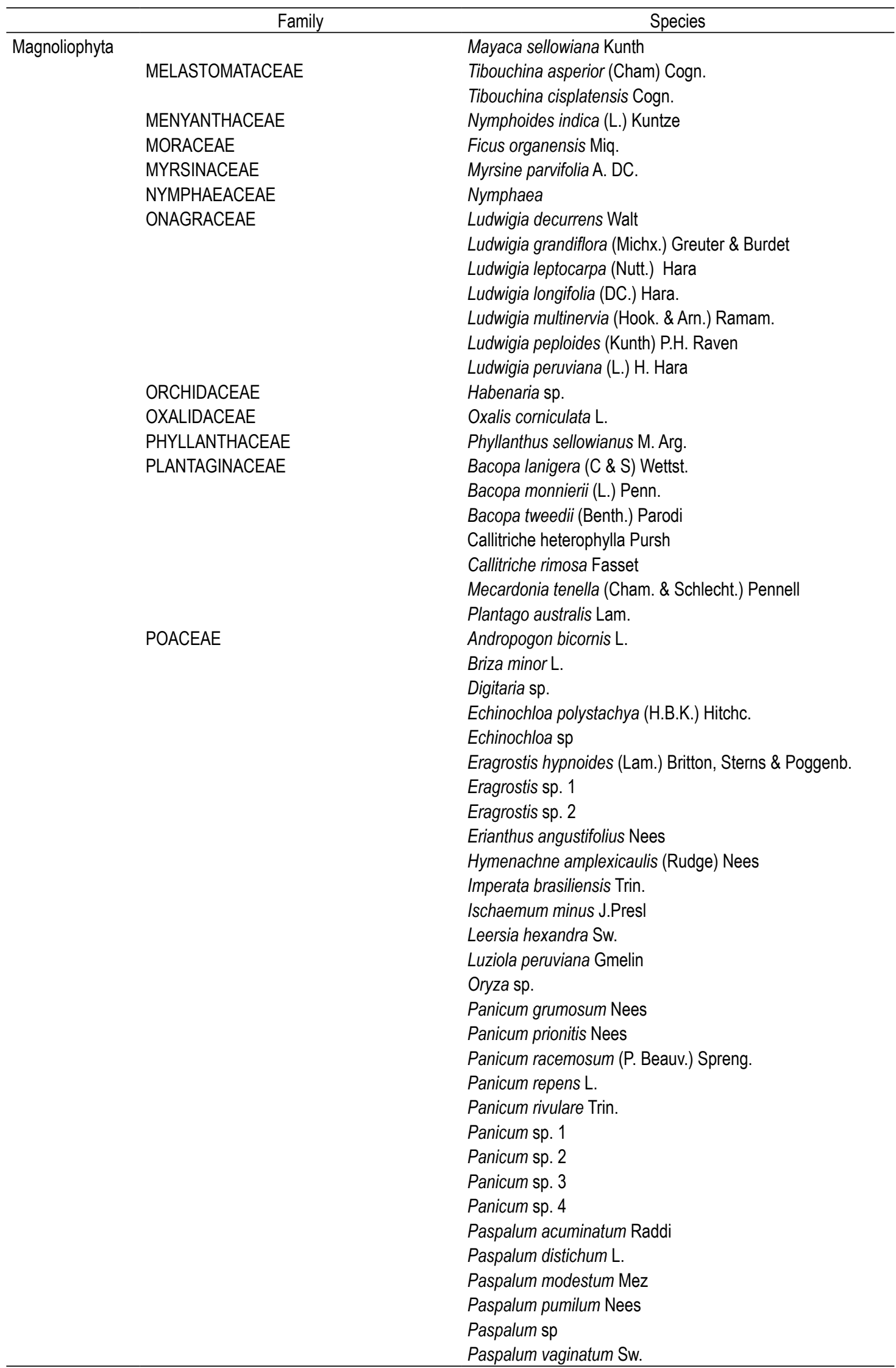


Table 1. Continued...

\begin{tabular}{|c|c|c|}
\hline & Family & Species \\
\hline \multirow[t]{38}{*}{ Magnoliophyta } & & Piptochaetium sp. \\
\hline & POLYGALACEAE & Polygala leptocaulis Torr. \& A.Gray \\
\hline & & Polygonum acuminatum H.B.K. \\
\hline & & Polygonum ferrugineum Wedd. \\
\hline & & Polygonum hidropiperoides Michx. \\
\hline & & Polygonum lapathifolium L. \\
\hline & & Polygonum meissnerianum Cham \& Schl. \\
\hline & & Polygonum persicaria L. \\
\hline & & Polygonum punctatum Ell. \\
\hline & & Polygonum setaceum Baldw. \\
\hline & & Polygonum sp. \\
\hline & & Polygonum stelligerium Cham. \\
\hline & & Rumex obovatus Danser \\
\hline & PONTEDERIACEAE & Eichhornia azurea (Sw.) Kunth \\
\hline & & Eichhornia crassipes (Mart.) Solms \\
\hline & & Heteranthera limosa (Sw.) Willd \\
\hline & & Heteranthera reiniformis Ruiz \& Pavon \\
\hline & & Heteranthera zosterifolia Mart. \\
\hline & & Pontederia cordata L. \\
\hline & POTAMOGETONACEAE & Potamogenton sp. \\
\hline & & Potamogeton ferrugineus Hagstr. \\
\hline & & Potamogeton spirilliformis Hagstr. \\
\hline & RANUNCULACEAE & Ranunculus apiifolius Persoon. \\
\hline & & Ranunculus bonariensis Poir. \\
\hline & & Ranunculus flagelliformis Smith \\
\hline & RUBIACEAE & Cephalanthus glabratus (Spreng.) K. Schum. \\
\hline & & Diodia alata Nees \& Mart. \\
\hline & & Diodia saponariifolia (Cham \& Schl.) K. Schum. \\
\hline & & Hedyotis salzmannii (DC.) Steud. \\
\hline & SALICACEAE & Salix humboldtiana Willd. \\
\hline & SOLANACEAE & Solanum americanum Mill. \\
\hline & & Solanum capsicoides All. \\
\hline & & Solanum glaucophyllum Desf. \\
\hline & THYMELAEACEAE & Daphnopsis racemosa Griseb. \\
\hline & TYPHACEAE & Typha dominguensis Pers. \\
\hline & & Typha latifolia L. \\
\hline & XYRIDACEAE & Xyris jupicai L.C.Rich \\
\hline & ZINGIBERACEAE & Hedychium coronarium Koenig \\
\hline
\end{tabular}

of the macrophyte community. In Rio Grande do Sul, regions of low altitude, such as the Coastal Plain and the Central Depression, present high density of wetlands (Maltchik et al., 2003) and are places of high richness of aquatic macrophytes (Figure 1). On the other hand, the low richness in the wetlands of the Upland may be result of the presence of small and isolated wetlands.

The hydrological fluctuation and hydroperiod are important attributes for macrophyte richness (Rolon and Maltchik, 2006; Maltchik et al., 2007). Macrophyte richness was significantly higher in permanent wetlands than in intermittent ones. Furthermore, the smallest and the highest species richness coincided with the lowest and the highest precipitation periods. Brose (2001) noticed that the hydroperiod can be more important than the area to predict the macrophyte richness in intermittent wetlands, where the water loss leads to local extinctions and/or dormancy of hydrophytes, which remain in the permanent wetlands. However, the recovery of the species richness following water table re-establishment is relatively fast in the intermittent wetlands, indicating that dormancy is probably an important plant strategy in these ecosystems.

The composition of aquatic macrophytes was determined, as for the richness, by several environmental attributes such: area, diversity of 
the habitats, altitude, water conductivity and nutrient concentration (Rolon and Maltchik, 2006; Rolon et al., 2008). A more detailed study in wetlands of Coastal Plain of Rio Grande do Sul has indicated that the structural characteristics of the ecosystem (area and diversity of habitat) and the water chemical conditions influenced independently the composition of the aquatic macrophytes, presenting additive effects on the macrophyte composition (Rolon et al., 2008). Wetland hydroperiod has also influenced macrophyte composition (Rolon et al., 2008). Among the species typical from permanent wetlands are some euhydrophytes (e.g., Azolla filiculoides, Hydrocotyle ranunculoides, Myriophyllum aquaticum, Salvinia herzogii and Utricularia foliosa).

Identifying the main environmental factors that determine the structure of aquatic macrophyte community is essential for establishing the guidelines for the biodiversity conservation of Southern Brazil. Proposals regarding the conservation of biodiversity normally prioritize large areas, with high species richness, high connectivity and occurrence of endemic species. The area was a determining factor for the richness and for the structure of the macrophyte composition in Southern Brazil, indicating that this factor should be considered in the management of the wetlands in Southern Brazil. However, other factors, such as, altitude, habitat diversity and hydroperiod, should be considered.

\subsection{Flood and macrophyte community dynamics in natural wetlands}

The floodplain systems are representative wetlands in Southern Brazil. The flood pulse concept suggests that the flood is an important event on the community structure and functioning of river-floodplain system (Junk et al., 1989). The flooding event is a complex variable, which encompasses several attributes (e.g. duration, frequency, amplitude and timing), which can affect the biota in different ways. According to Casanova and Brock (2000), the flood compromised the penetration of light and the ability of emergent plants to reach the surface by increasing the water depth. Therefore, the flood pulse can export the aquatic plants across the river-floodplain system.

The duration of the flood is an important agent of biological stability in wetland systems (Turner and Dale, 1998). Several studies have investigated the impact of the long-term floods in the aquatic vegetation in large river-floodplain systems (Junk, 1989; Ferreira, 2000; Padial et al., 2009); however, information regarding the effect of short-term floods on the structure of aquatic macrophytes is still rare in the literature. The changes of the environmental conditions due to long-term floods may change the structure of the macrophyte community by replacing the species, changing the richness and varying the biomass or the relative abundance of the species. In a shallow lake associated to the river floodplain, the stability of the macrophyte community was jeopardized after long-term floods (38 days), presenting alterations in both richness and total biomass of macrophytes (Maltchik et al., 2004). While short or very short-term floods ( 1 to 3 days) changed the biomass of the aquatic macrophyte assemblage, they did not modify the species richness (Schott et al., 2005; Maltchik et al., 2007).

Another important property of flood disturbance on community stability in aquatic ecosystems is the flood frequency. In Southern Brazil, the increase of the flood frequency, even the short-term ones, has reduced significantly the resistance of the macrophyte community (Maltchik et al., 2005). Furthermore, the absence of dominance was observed only in the shallow lake with the highest number of flood events (Maltchik et al., 2005). The decrease of resistance of the community may be related to the recurrence of floods, since the shortest interval between flood events may hinder the growth of the macrophyte and as consequence its reestablishment (Maltchik et al., 2005, 2007). The number of macrophyte species with modified biomass after the flooding events increased with the recurrence of floods in a floodplain palustrine wetland of Southern Brazil (Maltchik et al., 2007). While no species had their biomass modified after the first flood, the biomass of one and three species of macrophytes were modified after the subsequent floods (Maltchik et al., 2007).

The hydrological fluctuation and connectivity provided by the flood events affect the macrophyte diversity (Santos and Thomaz, 2007). Furthermore, flood and drawdown events affect directly the establishment and survival of aquatic plants (Blanch et al., 1999; Seabloom et al., 2001). The degree of tolerance of species to hydrological extremes (floods and drawdown events) determines the structure of macrophyte communities (Van Geest et al., 2005a, b). The alternation of hydrological phases (with floods, without floods and drawdown) has influenced the richness, biomass and the composition of aquatic macrophytes in several wetland types in Southern Brazil 
(Maltchik et al., 2005, 2007; Schott et al., 2005). In general, the lower richness of aquatic macrophyte was associated to the period of occurrence of floods (Maltchik et al., 2005, 2007; Schott et al., 2005). According to Gopal and Junk (2000), the hydrological fluctuation contributes to a high biodiversity in floodplain systems. The increase in the species richness in a subtropical palustrine wetland resulted of the resistance of several species during both hydrological extremes (flood and drought) and the establishment of new species along the drawdown phase (Maltchik et al., 2007).

The variation of the macrophyte biomass along the hydrological phases occurred differentially between the wetland types of Southern Brazil. While in some systems, the biomass was lower in flooded periods (Malchik et al., 2005); in others, the biomass was higher in the period without the presence of the surface water (Schott et al., 2005). According to Neiff (1975), while the peak of biomass of some macrophyte species occurs over the flood period, other species show high biomass values at low water level. These variations in the biomass peaks of species determine the dynamics of community biomass in floodplain systems. Maltchik et al. (2007) have noticed that the biomass peak of Eichhornia azurea during the flood phase and the biomass peak of Luziola peruviana and Eleocharis interstincta during the drawdown phase have contributed to maintain the mean biomass of macrophytes similar between both hydrological phases.

These results have indicated that the flood events, long or short-term ones, are strongly associated to the structure of the aquatic macrophyte community in several wetland types. Thus, any alteration in the hydrological regime (duration, frequency, etc.) will present several implications for the composition, richness and abundance of the aquatic macrophytes in wetlands of Southern Brazil.

\subsection{Rice fields and irrigation channels}

Rice fields have been recognized worldwide as having potential value for many aquatic species (Bambaradeniya and Amerasinghe, 2003; Elphick and Oring, 2003). Several new practices have been proposed to foster biodiversity conservation on agricultural wetlands as the management of water depth, ditches, and post-harvest straw (Bird et al., 2000; Tourenq et al., 2003; Manley et al., 2005). For instance, Californian rice producers usually flood their plantations after harvesting to accelerate straw decomposition. The intentional floods of rice fields had a positive effect on waterbird richness (Elphick and Oring, 1998).

In Southern Brazil, during the fallow phase, the agricultural land is drained and used to raise cattle. However, some rice fields are maintained flooded because they are located at lower areas susceptible to flood due to heavy rains in the winter. In this sense, the rice fields can be categorized as flooded or dry, according to the unintentional hydrological management practice after harvesting. In flooded rice fields, the surface water was present during all phases of the cycle, except in the tillage phase, whereas in the dry rice fields, the surface water was present only during the growing season (rice emergence and tillering). Accordingly, rice fields can be viewed as managed wetlands.

The rice field systems of Southern Brazil (crops and irrigation channel) shelter a representative number of species of macrophyte found at wetlands in this region. Along the cultivation cycle, which covers the cultivated and non-cultivated phases (fallow phases), was registered the presence of 88 species of aquatic macrophytes in six rice crops (Rolon et al., 2010) and 59 species in four irrigation channels (unpublished data). This macrophyte richness is similar to the results verified in rice fields in Asia and Europe (Vasconcelos et al., 1999; Bambaradeniya et al., 2004). However, the number of species was smaller than in wetlands of Southern Brazil (153 species - Rolon and Maltchik, 2006) and in wetlands adjacent to the study rice fields (105 species - Rolon et al., 2008).

Among the frequent species in the rice field systems, the outstanding species are Bulbostylis capillaris, Limnobium laevigatum, Ludwigia peploides, Luziola peruviana, Salvinia herzogii and Salvinia minima. Approximately $70 \%$ of the aquatic species were registered in the wetlands of Coastal Plain of Rio Grande do Sul State (Rolon and Maltchik, 2006; Rolon et al., 2008). However, the macrophyte composition in rice fields and in irrigation channels was different from that on natural wetlands, mainly due to the high dominance of grasses and sedges (Rolon et al., 2008). The dominance of grasses and sedges verified in rice fields and irrigation channels (c.a. 50\% of total species) is greater than the one found in most of the natural areas. The high dominance of grasses and sedges was also observed in rice fields of Sri Lanka (Bambaradenya et al., 2004). Furthermore, in the irrigation channels, hydrophytes (floating and submerged species) corresponded to $51 \%$ of all macrophyte species and emergent corresponded to 
$49 \%$ of macrophyte diversity. In natural wetlands, the hydrophytes represented only a small part of the community (c.a. $25 \%$ of species - Rolon et al., 2004). The morphology of the channels limits the establishment of emergent species to the littoral zone and the mean depth of $60 \mathrm{~cm}$ in the studied channels has provided more availability of habitats for the establishment of hydrophytes.

The agricultural practices adopted over rice cultivation cycle in the rice fields have influenced the macrophyte richness and biomass. The macrophyte richness and biomass in the tillage phase was lower than the two fallow phases and the end of the growing season. The low richness and biomass at the tillage phase can be a consequence of soil drainage, machine use and herbicide application. The absence of water during tillage phase suppressed the macrophyte species with low tolerance to drought and the use of machinery causes the revolving of soil and serious mechanical damages on plants. Furthermore, the control of aquatic macrophytes with herbicide (glyphosate) carried out during the tillage phase and in the beginning of the growing season was very evident, since most of the collected plants along the cultivation periods showed signs of tissue death. The irrigation channels, on the other hand, have not suffered the impact of the management practices adopted along the cultivation cycle, and the richness and biomass of macrophyte in such systems were constant over the year. One of the factors that may have contributed for the stability of the macrophyte assemblage was the permanence of the surface water along the whole period studied.

The different hydrological management practices adopted after the harvesting period (presence or lack of water surface) did not influence the macrophyte richness and biomass in the present study, however it has influenced the species composition. Like as in natural wetlands (Maltchik et al., 2007; Rolon et al., 2008), hydroperiod and water fluctuations are important determining factors for the macrophyte composition in rice fields. During uncultivated period (fallow phases), flooded and dry rice fields showed differences regarding the macrophyte composition, some hydrophytes (Azolla filiculoides, Salvinia minima, Ricciocarpus natans, Spirodella intermedia and Lemna valdiviana) characterized the flooded rice fields and some amphibian species (Bulbostylis capillaris, Centella asiatica, Hydrocotyle ranunculoides and Panicum spp.) discriminated the dry rice fields. The variation in species composition between flooded and dry rice fields may contribute to the similarity of richness and abundance of macrophytes in rice fields under different management practices. The difference in the species composition of flooded and dry rice fields is an important result concerning the conservation of biodiversity. Keeping the areas flooded and dry within the same farm could maximize habitats for the aquatic organisms up to $30 \%$ and should be considered as a strong conservational action.

Rice fields must not be viewed as surrogate systems for natural wetlands, given that natural wetlands are complex systems that have several functions (e.g. aquifer recharging, climatic stability and water storage). Furthermore, the macrophyte richness in rice fields is lower than in Southern Brazil wetlands, and the macrophyte composition was different from that on natural wetlands mainly due to the high dominance of grasses and sedges. However, the habitats provided by rice fields could contribute to increase the connectivity in a fragmented landscape, like as, Southern Brazil. The dispersion of macrophyte species is carried out by asexual or sexual propagules. Some macrophyte species reached their reproductive stages (flowers, seeds and oospores production). The production of sexual propagules could provide seeds for the seed bank formation in theses systems and contribute to the maintenance of genetic diversity of the populations, therefore, conserving the aquatic species of this region. It is worth highlighting that a great portion of the observed species in rice fields (47\%) was limited to one phase along the cultivation cycle, not able to reach the end of their life cycles in these ecosystems, but can providing asexual propagules. Furthermore, the network of irrigation channels can be used as ecological corridors for aquatic organisms dispersion (Armitage et al., 2003; Mazerolle, 2004).

\subsection{Macrophyte conservation}

The macrophyte richness related in this study (250 species) is a representative portion of richness estimated by Irgang and Gastal (1996) for wetlands of Rio Grande do Sul (400 to 500 species). At the wetlands of Southern Brazil, several environmental characteristics were determinant for the macrophyte richness and composition, such as, size, habitat diversity, altitude, hydroperiod, and flood maintenance. With regard to the conservation, the area may be an important criterion to be considered when choosing the priority areas for conservation. However, the influence of the habitat diversity must be considered, since several small 
wetlands have presented high habitat diversity and as consequence high macrophyte diversity. Although the richness is an important attribute for conservation, the difference in the composition of the species between the wetlands ( $\beta$-diversity) gives us better information concerning the conservation of the regional diversity of the species. Hence, the gradients - size, altitude and hydroperiod - that were determinant for the composition of the species should be preserved. Furthermore, the flood events, long or short-term ones, are strongly associated to the structure of the aquatic macrophyte community in several wetland types. Any alteration in the hydrological regime (duration, frequency, etc.) will present several implications for the composition, richness and abundance of the aquatic macrophytes in wetlands of Southern Brazil.

Actions concerning the minimization of the impact of the agricultural activities on the conservation of biodiversity are extremely relevant. Conservation of species in agroecosystems has attracted attention, mainly in Europe - where agricultural policy pays farmers to modify their farming practice to increase environmental benefits (CEC, 1985). The conservation of the macrophyte species in rice field may be an important strategy for biodiversity conservation in areas that the natural wetlands were converted into rice fields. Such strategy would minimized the agricultural impacts on aquatic plants diversity in Southern Brazil, where more than $90 \%$ of wetland systems have already been lost and the remaining ones are still at high risk due to the expansion of rice production.

\section{References}

AGOSTINHO, AA., THOMAZ, SM. and GOMES, LC. 2005. Conservation of the biodiversity of Brazil's inland waters. Conservation Biology, vol. 19, no. 3, p. 646-652.

ARMITAGE, PD., SZOSZKIEWICZ, K., BLACKBURN, JH. and NESBITT, I. 2003. Ditch communities: a major contributor to floodplain biodiversity. Aquatic Conservation: Marine and Freshwater Ecosystems, vol. 13, no. 2, p. 165-185.

ARRHENIUS, O. 1921. Species and area. Journal of Ecology, vol. 9, no. 1, p. 95-99.

BAMBARADENIYA, CNB. and AMERASINGHE, FP. 2003. Biodiversity associated with the rice field agroecosystem in Asian countries: a brief review. Sri Lanka: International Water Management Institute - IWMI. 24 p. IWMI Working Paper, no. 63.

BAMBARADENIYA, CNB., EDIRISINGHE, JP., SILVA, DN., GUNATILLEKE, CVS., RANAWANA, KB. and WIJEKOON, S. 2004. Biodiversity associated with an irrigated rice agroecosystem in Sri Lanka. Biodiversity and Conservation, vol. 13, no. 9, p. 1715-1753.

BERTOLUCI, VDM., ROLON, AS. and MALTCHIK, L. 2004. Diversidade de macrófitas aquáticas em áreas úmidas do município de São Leopoldo, Rio Grande do Sul, Brasil. Pesquisas: Botânica, vol. 55, p. 187-199.

BIRD, JA., PETTYGROVE, GS. and EADIE, JM. 2000. The impact of waterfowl foraging on the decomposition of rice straw: mutual benefits for rice growers and waterfowl. Journal of Applied Ecology, vol. 37, no. 5, p. 728-741.

BLANCH, SJ., GANF, GG. and WALKER, KF. 1999. Tolerance of riverine plants to flooding and exposure by water regime. Regulated Rivers: Research \& Management, vol. 15, no. 1-3, p. 43-62.

BROSE, U. 2001. Relative importance of isolation, area and habitat heterogeneity for vascular plant species richness of temporary wetlands in east-German farmland. Ecography, vol. 24, no. 6, p. 722-730.

CASANOVA, MT. and BROCK, MA. 2000. How do depth, duration and frequency of flooding influence the establishment of wetland plant communities? Plant Ecology, vol. 147, no. 2, p. 237-250.

Commission of the European Communities - CEC. 1985. Perspectives for the Common Agricultural Policy. Brussels: Communication from the Commission to the Council and the Parliament. $\operatorname{COM}(85)$ 333 final.

DAHLGREN, JP. and EHRLÉN, J. 2005. Distribution patterns of vascular plants in lakes - the role of metapopulation dynamics. Ecography, vol. 28, no. 1, p. $49-58$.

ELPHICK CS. and ORING, LW. 1998. Winter management of Californian rice fields for waterbirds. Journal of Applied Ecology, vol. 35, no. 1, p. 95-108.

ELPHICK, CS. 2000. Functional equivalency between rice fields and seminatural wetland habitats. Conservation Biology, vol. 14, no. 1, p. 181-191.

ELPHICK, CS. and ORING, LW. 2003. Conservation implications of flooding rice fields on winter waterbird communities. Agriculture, Ecosystems \& Environment, vol. 94, no. 1, p. 17-29.

FAOSTAT. 2008. FAO Statistical Databases. Available from: <http://faostat.fao.org $>$.

FERREIRA, LV. 2000. Effects of flooding duration on species richness, floristic composition and forest structure in river margin habitat in Amazonian blackwater floodplain forests: implications for future design of protected areas. Biodiversity and Conservation, vol. 9, no. 1, p. 1-14.

GEEST, GJ. van, COOPS, H., ROIJACKERS, RMM., BUIJSE, AD. and SCHEFFER, M. 2005a. Succession of aquatic vegetation driven by reduced 
water-level fluctuations in floodplain lakes. Journal of Applied Ecology, vol. 42, no. 2, p. 251-260.

GEEST, GJ. van, WOLTERS, H., ROOSEN, FCJM., COOPS, H., ROIJACKERS, RMM., BUIJSE, AD. and SCHEFFER, M. 2005b. Water-level fluctuations affect macrophyte richness in floodplain lakes. Hydrobiologia, vol. 539, no. 1, p. 239-248.

GOMES, AS. and MAGALHÃES Jr., AMD. 2004. Arroz Irrigado no Sul do Brasil. Pelotas: Embrapa. 900 p.

GOPAL, B. and JUNK, WJ. 2000. Biodiversity in wetlands: an introduction. In GOPAL, B., JUNK, WJ. and DAVIES, JA. (Eds.). Biodiversity in Wetlands: Assessment, Function and Conservation. Leiden: Backhuys Publishers. p. 1-10.

GOULDER, R. 2008. Conservation of aquatic plants in artificial watercourses: Are main drains a substitute for vulnerable navigation canals? Aquatic Conservation: Marine and Freshwater Ecosystems, vol. 18, no. 2, p. 163-174.

HALL, DL., WILLIG, MR., MOORHEAD, DL., SITES, RW., FISH, EB. and MOLLHAGEN, TR. 2004. Aquatic macroinvertebrate diversity of playa wetlands: the role of landscape and island biogeographic characteristics. Wetlands, vol. 24, p. 77-91.

HERZON, I. and HELENIUS, J. 2008. Agricultural drainage ditches, their biological importance and functioning. Biological Conservation, vol. 141, no. 5, p. 1171-1183.

IRGANG, BE. and GASTAL Jr., CVS. 1996. Macrófitas aquáticas da Planície Costeira do RS. Porto Alegre. $290 \mathrm{p}$.

JONES, JI., LI, W. and MABERLY, SC. 2003. Area, altitude and aquatic plant diversity. Ecography, vol. 26, no. 4, p. 411-420.

JULIANO, BO. 1993. Rice in human nutrition. Philippines: Food and Agriculture Organization -FAO, International Rice Research Institute - IRRI. $162 \mathrm{p}$.

JUNK, WJ. 1989. Flood tolerance and tree distribution in central Amazonia. In HOLM-NIELSEN, LB., NIELSEN, IC. and BALSLEV, H. (Eds.). Tropical Forest Botanical Dynamics, Speciation and Diversity. London: Academic Press. p. 47-64.

KOHN, DD. and WALSH, DM. 1994. Plant species richness - the effect of island size and habitat diversity. Journal of Ecology, vol. 82, no. 2, p. 367-377.

LEWINSOHN, TM. and PRADO, PI. 2005. How many species are there in Brazil? Conservation Biology, vol. 19, no.3, p. 619-624.

MALTCHIK, L. 2003. Three new wetlands inventories in Brazil. Interciencia, vol. 28, no. 7, p. 421-423.

MALTCHIK, L., COSTA, ES., BECKER, CG. and OLIVEIRA, AE. 2003. Inventory of wetlands of Rio Grande do Sul (Brazil). Pesquisas: Botânica, vol. 53, p. 89-100.
MALTCHIK, L., OLIVEIRA, GR., ROLON, AS. and STENERT, C. 2005. Diversity and stability of aquatic macrophyte community in three shallow lakes associated to a floodplain system in the South of Brazil. Interciencia, vol. 30, no. 3, p. 166-170.

MALTCHIK, L., ROLON, AS. and GROTH, c. 2002. Diversidade de macrófitas aquáticas em áreas úmidas da Bacia do Rio dos Sinos, Rio Grande do Sul. Pesquisas: Botânica, vol. 52, p. 143-154.

MALTCHIK, L., ROLON, AS. and SCHOTT, P. 2007. Effects of hydrological variation on the aquatic plant community in a floodplain palustrine wetland of Southern Brasil. Limnology, vol. 8, no. 1, p. 23-28.

MALTCHIK, L., ROLON, AS., GUADAGNIN, DL. and STENERT, C. 2004. Wetlands of Rio Grande do Sul, Brazil: a classification with emphasis on plant communities. Acta Limnologica Brasiliensia, vol. 16, no. 2, p. 137-151.

MANLEY, SW., KAMINSKI, RM., REINECKE, KJ. and Gerard, PD. 2005. Agronomic implications of waterfowl management in Mississippi ricefields. Wildlife Society Bulletin, vol. 33, no. 3, p. 981-992.

MARSHALL, EJP., BROWN, VK., BOATMAN, ND., LUTMAN, PJW., SQUIRE, GR. and WARD, LK. 2003. The role of weeds in supporting biological diversity within crop fields. Weed Research, vol. 43, no. 1, p. 77-89.

MAZEROLLE, MC. 2004. Drainage ditches facilitate frog movements in a hostile landscape. Landscape Ecology, vol. 20, no. 5, p. 579-590

Millennium Ecosystem Assessment. 2005. Ecosystems and human well-being: wetlands and water. Washington: World Resources Institute. 80 p.

MITSCH, WJ. and GOSSELINK, JG. 2000. Wetlands. New York: John Wiley and Sons. 920 p.

NEIFF, JJ. 1975. Fluctuaciones anuales en la composition fitocenotica y biomasa de la hidrofita en lagunas isleñas del Parana Medio. Ecosur, vol. 2, no. 4, p. 153-183.

OERTLI, B., JOEY, DA., CASTELLA, E., JUGE, R., CAMBIN, D. and LACHAVANNE, JB. 2002. Does size matter? The relationship between pond area and biodiversity. Biological Conservation, vol. 104, no. 1, p. 59-70.

Organization for Economic Co-operation and Development - OECD. 1996. Guidelines for aid agencies for improved conservation and sustainable use of tropical and subtropical wetlands. Paris: OECD.

PADIAL, AA., CARVALHO, P., THOMAZ, SM., BOSCHILIA, SM., RODRIGUES, RB. and KOBAYASHI, JT. 2009. The role of an extreme flood disturbance on macrophyte assemblages in a Neotropical floodplain. Aquatic Sciences, vol. 71, no. 4, p. 389-398.

RICKLEFS, RE. and LOVETTE, IJ. 1999. The roles of island area per se and habitat diversity in the species- 
area relationships of four Lesser Antillean faunal groups. Journal of Animal Ecology, vol. 68, no. 6, p. 1142-1160.

ROLON, AS. and MALTCHIK, L. 2006. Environmental factors as predictors of aquatic macrophyte richness and composition in wetlands of Southern Brazil. Hydrobiologia, vol. 556, no. 1, p. 221-231.

ROLON, AS. and MALTCHIK, L. 2010. Does flooding of rice fields after cultivation contribute to wetland plant conservation in southern Brazil? Applied Vegetation Science, vol. 13, no. 1, p. 26-35.

ROLON, AS., LACERDA, T., MALTCHIK, L. and GUADAGNIN, DL. 2008. The influence of area, habitat and water chemistry on richness and composition of macrophyte assemblages in southern Brazil wetlands. Journal of Vegetation Science, vol. 19, no. 2, p. 221-228.

ROLON, AS., MALTCHIK, L. and IRGANG, B. 2004. Levantamento de macrófitas aquáticas em áreas úmidas do Rio Grande do Sul, Brasil. Acta Biologica Leopoldensia, vol. 26, no. 1, p. 17-35.

ROSENZWEIG, ML. 1995. Species diversity in space and time. Cambridge: Cambridge University Press. $460 \mathrm{p}$.

SANTOS, AM. and THOMAZ, SM. 2007. Aquatic macrophyte diversity in lagoons of a tropical floodplain: The role of connectivity an water level. Austral Ecology, vol. 32, no. 2, p. 177-190.
SCHOTT, P., ROLON, AS. and MALTCHIK, L. 2005. The dynamics of macrophytes in an oxbow lake of the Sinos River basin in south Brazil. Verhandlungen. Internationale Vereinigung fuer theoretische und angewandte Limnologie, vol. 29, no. 2, p. 815-820.

SEABLOOM, EW., MALONEY, KA. and VALK, AG. van der. 2001. Constraints on the establishment of plants along a fluctuating water-depth gradient. Ecology, vol. 82, no. 8, p. 2216-2232.

SHINE, C. and KLEMM, C. 1999. Wetlands, water and the law: using law to advance wetland conservation and wise use. Gland: IUCN. 348 p.

TOURENQ, C., SADOUL, N., BECK, N., MESLÉARD, F. and MARTIN, JL. 2003. Effects of cropping practices on the use of rice fields by waterbirds in the Camargue, France. Agriculture, Ecosystems \& Environment, vol. 95, no. 2-3, p. 543-549.

TURNER, MG. and DALE, VH. 1998. Comparing large and infrequent disturbances: what have we learned? Ecosystems, vol. 1, no. 6, p. 493-496.

VASCONCELOS, T., TAVARES, $M$. and GASPAR, N. 1999. Aquatic plants in the rice fields of the Tagus valley, Portugal. Hydrobiologia, vol. 415, no. 1, p. 59-65.

Received: 24 February 2010 Accepted: 12 August 2010 